\title{
LEXICAL DENSITY AND READABILITY IN ENGLISH FOR JUNIOR HIGH SCHOOL VIII TEXTBOOK
}

\author{
*Nurwahidah Ramadhani Waruwu \\ **Johan Sinulingga \\ **Yeni Erlita \\ Universitas Negeri Medan
}

\begin{abstract}
Waruwu, Nurwahidah Ramadhani. Registration Number: 2123121039. Lexical Density and Readability in English for Junior High School VIII Textbook. A Thesis. English Educational Program, State University of Medan, 2018.

This study aimed to analyze and describe the lexical density and readability in English for Junior High School VIII textbook. It was conducted by using descriptive qualitative research. The textbook was published by Mediatama. It is used for the eighth grade of students in junior high school. The researcher used seven reading texts as the data. The lexical density was tested by using Ure's formula and the readability was tested by using Flesch Reading Ease Formula. The result showed that the lexical density of the reading texts in English for Junior High School VIII textbook is above $40 \%$ which indicates that it has high lexical density. Lexical items (nouns, verbs, adjectives, and adverbs) play important role to influence the density of a text. The more lexical items in a text, the higher lexical density percentage will be and it also affects the readability of the reading texts. Then, the result also showed that the average readability score is 66 which falls into standard level. It indicates that the reading texts are readable for $8^{\text {th }}$ grade students of junior high school but they still need teacher's assistance to comprehend the texts.
\end{abstract}

Keywords: Lexical Density, Readability, Flesch Reading Ease Formula.

\footnotetext{
*Graduate Status

** Lecturer Status
} 


\title{
LEXICAL DENSITY AND READABILITY IN ENGLISH FOR JUNIOR HIGH SCHOOL VIII TEXTBOOK
}

\author{
*Nurwahidah Ramadhani Waruwu \\ **Johan Sinulingga \\ **Yeni Erlita
}

\begin{abstract}
Waruwu, Nurwahidah Ramadhani. Registration Number: 2123121039. Lexical Density and Readability in English for Junior High School VIII Textbook. A Thesis. English Educational Program, State University of Medan, 2018.
\end{abstract}

This study aimed to analyze and describe the lexical density and readability in English for Junior High School VIII textbook. It was conducted by using descriptive qualitative research. The textbook was published by Mediatama. It is used for the eighth grade of students in junior high school. The researcher used seven reading texts as the data. The lexical density was tested by using Ure's formula and the readability was tested by using Flesch Reading Ease Formula. The result showed that the lexical density of the reading texts in English for Junior High School VIII textbook is above $40 \%$ which indicates that it has high lexical density. Lexical items (nouns, verbs, adjectives, and adverbs) play important role to influence the density of a text. The more lexical items in a text, the higher lexical density percentage will be and it also affects the readability of the reading texts. Then, the result also showed that the average readability score is 66 which falls into standard level. It indicates that the reading texts are readable for $8^{\text {th }}$ grade students of junior high school but they still need teacher's assistance to comprehend the texts.

Keywords: Lexical Density, Readability, Flesch Reading Ease Formula.

\footnotetext{
*Graduate Status

** Lecturer Status
} 


\section{INTRODUCTION}

\section{Background of Study}

Teaching English as foreign language in Indonesia involves four integrated skills: listening, speaking, reading and writing. Reading is an important skill and plays a dominant role among the four skill used in the learning of the English language (Alhaisoni, 2017: 30). Reading is a receptive skill, it means readers receive the language and interpret the meaning to get the information. In junior high school level, the standard competency of reading in Kurikulum Tingkat Satuan Pendidikan (KTSP) is the students are able to understand a simple genre based texts. In order to reach the goal, teachers usually use textbook as one of the main media in teaching and learning process.

In Indonesia, textbook has always been a media used in all schools and all grades. Textbooks are usually distributed to the teachers and students in the first month of academic year. In this case, most of the schools or teachers will choose a textbook which is appropriate with the curriculum. Teachers usually use textbook as the media to facilitate the teaching and learning process. A textbook is expected to make learning easier and more enjoyable because it contains the syllabus for the course with a set of exercises, such as reading materials, listening tasks, stories, clear instructions, games, tests, assessment rubrics, glossaries, etc. By using textbook, students can learn not only in the classroom but they can also repeat the materials and prepare themselves for the next material at home.

It can be said that reading and textbook has strong relationship. As mentioned above, reading material is one of the content of a textbook. Textbook 
provides reading materials which are expected to enhance reading ability of the students. In reading section, reading a text and answering some questions are some common activities that teacher asked the students to do. A reading text is usually arranged in some paragraphs. Questions are arranged for the purpose of assessing their comprehension about the content of the text.

Based on researcher's observation in SMPN 1 Tanjung Pura, the researcher found some information by interviewing the teachers and the students. The teachers said that the students have difficulty in understanding reading texts because they have limited vocabularies. This situation relates to lexical density of the text. Lexical density talks about how information a text is by analyzing the content words (noun, verb, adjective, and adverb). Furthermore, the students said that some texts are too long and there are many unfamiliar words in a text. They have to look for the meaning of many words by using dictionary. It wasted a lot of time. Some teachers often help them by giving the meaning of the text in bahasa Indonesia. This problem relates to readability of the text. Readability talks about the level of ease or difficulty a text to the particular reader.

Those two problems lead the researcher to investigate the lexical density and the readability of reading texts in a textbook because it relates to the students' comprehension. These two terms are caused reading difficulty (Nesia, 2014, Lestari, Kifli 2016).

Lexical density is a way to measure how dense the text is. It is often used for describing the proportion of content words to the total number of words (Johansson, 2008:65). Content words are also known as lexical items (nouns, 
verbs, adjectives and also adverb). They carry information for the readers. So, lexical density relates to the vocabularies.

Halliday (1985:63) points out that lexical items enter into open system which is indefinitely extendable. One word may have more than one meaning depends on the context. Ure's study (in Johansson, 2008:65) finds out the written texts had a density of $40 \%$ or more. Further, Lestari (2016:2) states a statement about the level of lexical density "for foreign language learners, the text which content of high content words will make students got trouble to understand the text". Consequently, the learners are potentially facing problems to comprehend the text.

The other thing that influences reading difficulty is readability. Readability is a concept that describes the degree in which a text is easy or difficult to be read (Brown, Janssen, and Trace, 2012:1). It is important to find out the level of readability to minimize the students get difficulty in reading activity. It is also supported by National Education Standards Agency (BSNP) statement which is written in Bulletin 21 ${ }^{\text {st }}$ edition (2007:21). They set some aspects as the criteria of textbook. One of the aspect is the feasibility of language. The indicator that considered in the feasibility of language is the readability of the text. So, readability is one of the main point for selecting reading materials in school.

The most popular way to measure readability is by using formula (Dubay, 2004:2). Readability of the reading texts can be measured by considering the number of words, syllables, and sentences. It is known as Flesch Reading Ease Formula. Flesch only uses two variables, the number of syllables and the number 
of sentences for each 100-word sample. He also sets a scale from 1 to 100, with 30 being "very difficult" and 70 being "easy." The score 60-70 is described as standard/plain English which is suitable for $8^{\text {th }}-9^{\text {th }}$ grade. If the score is under 60 , it is not appropriate for that grade because the text is too difficult for the students and if the score is above 70, the text is also not appropriate because it is too easy.

Based on the explanation above, it is important to find out the lexical density and the readability of textbook because it directly affects the students' in learning process especially in improving reading skill. In this research, the researcher decides to analyze English for Junior High School VIII textbook which was published by Mediatama. The textbook is used for the eighth grade of students in some junior high schools. By doing this research, the researcher can provide the data that can be used as the consideration for the teacher in choosing appropriate reading texts or textbook which is suitable to the students' level and need.

\section{REVIEW OF LITERATURE}

Johansson (2008:65) explains that lexical density is the term most often used for describing the proportion of content words (nouns, verbs, adjectives, and often also adverbs) to the total number of words. By investigating this, we receive a notion of information packaging, a text with a high proportion of content words contains more information than a text with a high proportion of function words (prepositions, interjections, pronouns, conjunctions).

In same line, Eggins (2004:97) states that the lexical density of a text can be calculated by expressing the number of content carrying words in a 
text/sentence as a proportion of all the worlds in the text/sentence. Content carrying words include nouns, the main part of the verb, adverbs and adjectives. Non-content carrying words include prepositions, conjunctions, auxiliary verbs and pronouns.

The measurement of lexical density originally was proposed by Ure in 1971 (as quoted in To, 2013: 62) that lexical density should be treated as the proportion of the number of lexical words per number of running words. Halliday (1985:64) also states that lexical density is the number of lexical items as a proportion of the number of running words.

Table 1. The Measurement of Lexical Density based on Ure's Theory (Ure, 1971 in To, 2013:63; Halliday, 1985:64)

$$
\text { Lexical density percentage: } \frac{\text { number of content words }}{\text { total number of words }} \times 100
$$

Ure also concludes that a large majority of the spoken texts have a lexical density under $40 \%$, while a large majority of the written texts have a lexical density is about $40 \%$ or higher (Johansson, 2008:65). It means that if the result of a text is above $40 \%$, it can be stated that it is written language and it has higher lexical density. It also proves that if the text highly dense, the more information there is and it can make the readers get difficulty in comprehending the text.

The other thing that influences reading difficulty is readability. Dubay (2004:3) states that readability is what makes some texts easier to read than others. Then, Richards and Schmidt (2002:442) define "readability as how easily written materials can be read and understood". Further, Pikulski (2002:1) states 
that readability is the level of ease or difficulty with which text material can be understood by a particular reader who is reading that text for a specific purpose.

Readability depends on many factors, including (a) the average length of sentences in a passage (b) the number of new words a passage contains (c) the grammatical complexity of the language used. Procedures used for measuring readability are known as "readability formulae" (Richards \& Schmidt, 2002:442).

This study implemented Flesch Reading Ease Formula to measure readability of the textbook. It is supported by Chall and Klare (as quotes in Dubay, 2004: 21), who known as the researchers of readability, state that Flesch's Reading Ease Formula became the most widely used formula and one of the most tested and reliable.

Flesch Reading Ease Formula only uses two variables, the number of syllables and the number of sentences for each 100-word sample. It predicts reading ease on a scale from 1 to 100 , with 30 being "very difficult" and 70 being "easy." The detail description about the scales describe below:

Table 2. Flesch Reading Ease Score (Dubay: 2004: 21)

\begin{tabular}{|c|c|c|c|}
\hline $\begin{array}{l}\text { Reading } \\
\text { Score }\end{array}$ & Ease & $\begin{array}{l}\text { Description of } \\
\text { Style }\end{array}$ & Estimated Reading Grade \\
\hline 0 to 30 & & Very Difficult & College Graduate \\
\hline 30 to 50 & & Difficult & $13^{\text {th }}$ to $16^{\text {th }}$ grade (College) \\
\hline 50 to 60 & & Fairly Difficult & $10^{\text {th }}$ to $12^{\text {th }}$ grade \\
\hline 60 to 70 & & Standard & $8^{\text {th }}$ and $9^{\text {th }}$ grade \\
\hline 70 to 80 & & Fairly Easy & $7^{\text {th }}$ grade \\
\hline 80 to 90 & & Easy & $6^{\text {th }}$ grade \\
\hline 90 to 100 & & Very Easy & $5^{\text {th }}$ grade \\
\hline
\end{tabular}




\section{RESEARCH METHODOLOGY AND FINDINGS}

Methodology

The researcher conducted the research by using descriptive qualitative research in order to find out lexical density and readability in the reading texts of English for Junior High School VIII textbook.

The textbook was published by Mediatama. It is used for the eighth grade of students in junior high school. There are fourteen reading texts, but the researcher used seven reading texts as the data.

\section{Techniques of Analyzing the Data}

In analyzing the lexical density, the researcher counted the total number of words, and identified the content words/lexical items. Then, calculated the percentage by using Ure's Formula.

In analyzing the readability, the researcher took 100 words as sample from each text. Then, counted the number of words, the number of sentences, the number of syllables, the number of average sentence length (ASL), and the average number of syllable per words (ASW). Then, calculated the score by using Flesch Reading Ease Formula.

\section{Findings}

After analyzing the seven chosen texts, there were some findings as explained below:

1. The result of lexical density analysis as follows; text 1 gains $59.4 \%$, text 2 gains $60 \%$, text 3 gains $56.3 \%$, text 4 gains $40 \%$, text 5 gains $51.3 \%$, text 6 gains $45.1 \%$, and text 7 gains $54.9 \%$. Based on Ure's explanation which states that 
if the result is above $40 \%$, it can be stated that they are suitable as written language and they have high lexical density.

2. Lexical items determine the density of the text. From seven reading texts, 5 texts (Seasons in Indonesia, The Four Seasons, Birthday Tradition around the World, Surprising Monday, and Prambanan Temple) have more lexical items than grammatical items and it affects the lexical density. On the other hand, Unlucky Sunday and The Legend of Lake Toba which have more grammatical items than lexical items get lower percentage among others. The analysis' results show that the more lexical items in a text, the higher lexical density percentage will be.

3. There are 3 texts categorized into fairly difficult level. They are Seasons in Indonesia (54), The Four Seasons (50), and Birthday Tradition around the World (51). Based on Flesch Reading Ease Formula, the texts are estimated for $10^{\text {th }}$ to $12^{\text {th }}$ grade and are predicted to be too hard for eighth grade.

4. There are 2 texts categorized into fairly easy level. They are Surprising Monday (74) and Prambanan Temple (70). Based on Flesch Reading Ease Formula, the texts are estimated for $7^{\text {th }}$ grade and are predicted to be too easy for eighth grade.

5. There are 2 texts categorized into easy level. They are Unlucky Sunday (82) and The Legend of Lake Toba (85). Based on Flesch Reading Ease Formula, the texts are estimated for $6^{\text {th }}$ grade and are predicted to be too easy for eighth grade. 


\section{CONCLUSIONS AND SUGGESTIONS}

\section{Conclusions}

After analyzing seven reading texts in English for Junior High School VIII textbook, the researcher can conclude that:

1. The lexical density of the reading texts in English for Junior High School VIII textbook are above $40 \%$ which indicate that it is suitable for written language and has high lexical density. Lexical items (nouns, verbs, adjectives, and adverbs) play important role to influence the density of a text. The more lexical items in a text, the higher lexical density percentage will be and it also affects the readability of the reading texts.

2. The readability of the seven representative texts in English for Junior High School VIII textbook varies from $6^{\text {th }}$ grade to $12^{\text {th }}$ grade, but the average readability score is 66 which falls into standard level. It indicates that the reading texts are readable for $8^{\text {th }}$ grade students of junior high school but they still need teacher's assistance to comprehend the texts.

\section{Suggestions}

The following are some suggestions for teachers, the writers of textbook, and other researchers.

1. For teachers

It is recommended for teachers to understand the lexical density and readability theories, so they can seek the lexical density and readability of reading texts. The score can be used as consideration in choosing appropriate texts which are suitable for students' need and level. 
2. For writers of textbook

It is better for writers of textbook to pay attention about the lexical density and readability of reading texts before they write, arrange or put a text into textbook. Lexical items (which affects lexical density) and readability are included as criteria for feasibility of language that is supported by National Education Standards Agency (BSNP). So, in writing or arranging the texts, the writers of textbook should deal with students' need and level.

\section{For other researchers}

It is better for other researcher to conduct similar research to enrich the study about lexical density and readability. 


\section{REFERENCES}

Alhaisoni, Eid. 2017. Prior Knowledge in EFL Reading Comprehension: Native and Nonnative EFL Teachers' Perceptions, Classroom Strategies, and Difficulties Encountered. International Journal on Studies in English Language and Literature (IJSELL), 5 (1), pp. 30-41

Brown, James Dean, Janssen, Gerriet., \& Trace, Jonathan. 2012. A Preliminary Study of Cloze Procedure as a Tool for Estimating English Readability for Russian Students. Second Language Studies, 31 (1), pp. 1-22.

BSNP. 2007. Kegiatan Penilaian Buku Teks Pelajaran Pendidikan Dasar dan Menengah. Buletin BSNP, II (1).

Dubay, W. H. (2004). The Principles of Readability. California: Impact Information.

Eggins, Suzanne. 2004. An Introduction to Systemic Functional Linguistics Second Language. New York: Continuum International Publishing Group.

Flesch, Rudolf. 1949. The Art of Readable Writing. New York: Harper \& Row Publisher.

Halliday, M. A. K. 1985. Spoken and Written Language. New York: Oxford University Press.

Johansson, Victoria. 2008. Lexical diversity and lexical density in speech and writing: a development perspective. Working press 53:61-79.

Kifli, Barli. 2016. The Readability of Reading Texts in English Textbooks for the Eighth Grade Students in Medan in The Academic Year of 2015/2016. Unpublished Thesis: Universitas Negeri Medan.

Lestari, Rini. 2016. Lexical Density and Grammatical Intricacy of Reading Materials to the Tenth Grade Students of Senior High School. Unpublished Thesis: Universitas Negeri Medan.

Nesia, Besyebah H. 2014. Lexical Density of English Reading Texts for Senior High School. Unpublished thesis: Universitas Negeri Medan.

Pikulski, J.J. 2002. Readability. U.S: Houghton Mifflin, pp. 1-12.

Richards, J. C. 2001. The Role of Textbook in a Language Program. Cambridge: Cambridge University Press. 
Richards, Jack C. \& Schmidt, Richard. 2002. Longman Dictionary of Language Teaching \& Applied Linguistics. London: Pearson Education.

To, Vinh, Fan, Si., \& Thomas, Damon. 2013. Lexical Density and Readability: A Case Study of English Textbooks. Internet Journal of Language, Culture, and Society, 37:61-71 